Juha-Matti Tammela

FL, lehtori, oppikirjailija, Maunulan yhteiskoulu ja Helsingin matematiikkalukio

\title{
KOULUKINOKOULUISTA 2020-LUVUN ILMIÖ
}

Koulumaailmassa on kansainvälisestikin tarkasteltuna ollut jo pitkään erilaisia tunnuksia, lippuja ja sertifikaatteja, joilla on kannustettu yhteisen hyvän edistämiseen. Koulut ovat lähteneet mukaan, sillä käyttöön saatavat logot ovat näkyvä ja kätevä tapa ilmaista arvomaailmaa ja kertoa toiminnasta. Toisaalta nuorilla on etenkin kaupungeissa vaihtoehtoisia opinahjoja, mikä tekee kouluista brändin rakentajia. Esimerkiksi KiVa-kouluissa toteutetaan kiusaamisen vastaista, ennalta ehkäisevää työtä, ja YK-kouluissa korostetaan ihmisoikeuksien, rauhan ja turvallisuuden aiheita. Vihreä lippu -kouluissa on sitouduttu kestävään kehitykseen. Joukkoon ovat tulleet nyt myös koulukinokoulut, joiksi oppilaitokset voivat hakea olemalla yhteydessä Koulukino ry:hyn.

Koulukino ry:n (www.koulukino.fi) myöntämän sertifikaatin saaneissa kouluissa toteutetaan esimerkillistä elokuvakasvatusta luontevana osana koulun arkea. Yhdistys valitsi Pohjois-Helsingissä sijaitsevan Maunulan yhteiskoulun ja Helsingin matematiikkalukion (www.mayk.fi) pilottikoulukseen testaamaan ja kehittämään sertifikaatin kriteeristöä. Oppilaitoksessa toimivat peruskoulun yläluokat, kansainväliset luokat, yleislukio ja matematiikkalukio. Oppilaita ja opiskelijoita on yli 800.

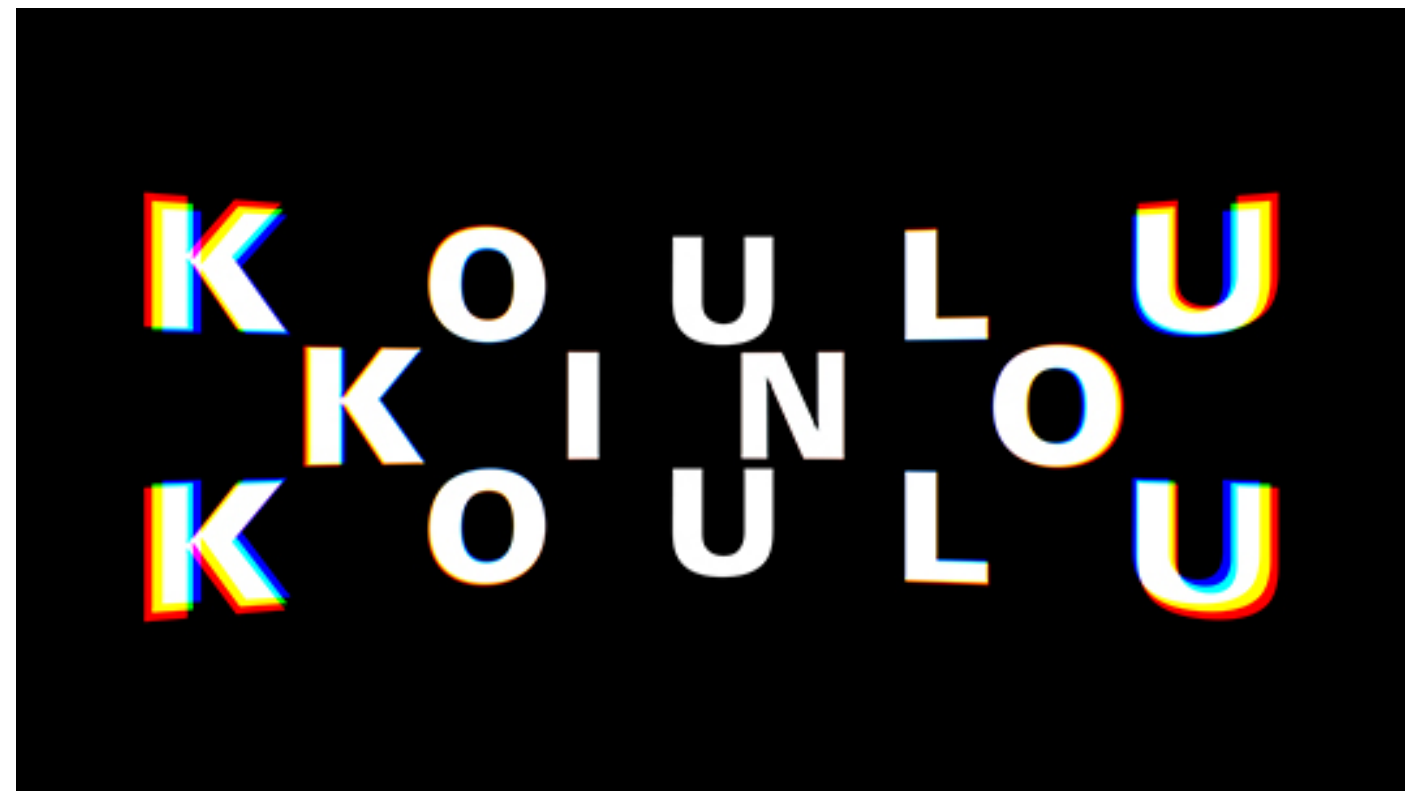

Kuva 1. Koulut voivat lähettää vapaamuotoisen hakemuksen koulukinokouluksi Koulukinoyhdistykseen. Kuvassa on Koulukinokoulun logo. 
Yhdistys perusteli valintaansa Maunulassa toteutetuilla runsailla koulukinonäytännöillä (keskimäärin 5-6 tilausnäytäntöä lukuvuodessa) ja sillä, että elokuvakasvatus on ollut kiinteä osa oppiaineiden välistä opetusyhteistyötä ja yhteisöllisyyden luomisen keino jo vuosia.

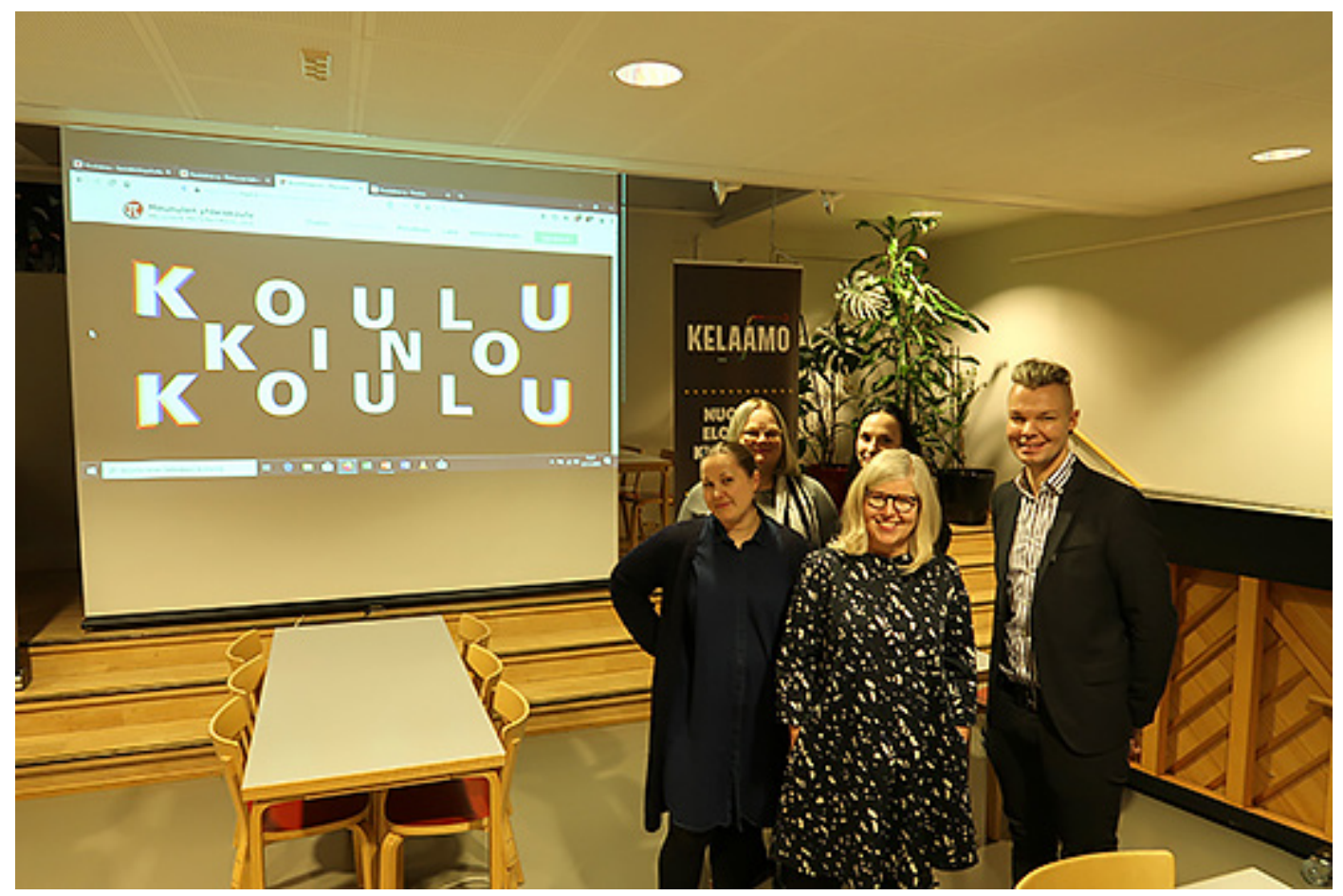

Kuva 2. Suomen ensimmäinen koulukinokoulu valittiin 27.11.2019. Kuvassa edessä keskellä on Koulukino ry:n toiminnanjohtaja Outi Freese ja hänen takanaan Koulukinon erityisasiantuntijat Heli Metsätähti, Hanna Laurinsalo ja Marjo Kovanen, oikealla Maunulan yhteiskoulun ja Helsingin matematiikkalukion koulukinokoordinaattori Juha-Matti Tammela. Valokuva: Salli Kulmala.

- Koulukinokoulu-sertifikaatti myönnetään oppilaitaan elokuvateatteriin vieville, elokuvakasvatusta esimerkillisesti toteuttaville kouluille.

- Sertifikaattia voi hakea koulu, joka tilaa vähintään kaksi koulukinonäytäntöä elokuvateatterista lukuvuoden aikana ja käyttää Koulukinon oppimateriaaleja.

- Koulukinokoulut ovat mukana testaamassa uusia elokuvia ja niiden oppimateriaaleja.

- Mahdollisuuksien mukaan koulu käyttää myös Koulukino Suoratoisto -palvelua integroituna opetukseen.

- Maunulan yhteiskoulu ja Helsingin matematiikkalukio on Suomen ensimmäinen koulukinokoulu.

(Koulukinoyhdistys 2019) 


\section{Opetussuunnitelmat perustelevat elokuvakasvatuksen}

Paraikaa käytössä olevat perusopetuksen ja lukion opetussuunnitelmien perusteet (2014 ja 2015) ja vuonna 2019 julkaistut lukion opetussuunnitelman perusteet, joiden pohjalta rakennettavat koulukohtaiset opetussuunnitelmat astuvat voimaan 1.8.2021, ovat avanneet elokuvan käytölle opetuksessa entistäkin enemmän mahdollisuuksia. Paikoin ne jopa vaativat hyödyntämään elokuvaa. Elokuva on perinteisesti ollut osa kuvataiteen ja jossain määrin myös äidinkielen ja kirjallisuuden oppisisältöjä. (Opetushallitus 2014, 19, 21; Opetushallitus 2015, 12-13, 15; Opetushallitus 2019, 66, 71.) Elokuva sopii kuitenkin lähes minkä tahansa asian opettamiseen ja on lopulta myös yksi helpoimmista tavoista yhdistää eri oppiaineet.

Vuonna 2015 julkaistujen lukion opetussuunnitelmien perusteiden yleisessä osassa puhutaan siitä, kuinka lukioiden tulee tehdä yhteistyötä koulun ulkopuolisten paikallisten toimijoiden kanssa. Vuoden 2019 lukion opetussuunnitelman perusteissa mainitaan suoraan teatterit ja muut kulttuurilaitokset (Opetushallitus 2019, 66). Nyt käytössä olevassa ja tulevassa opetussuunnitelmassa tuodaan siis esille se, että koulun on laajennuttava fyysisestä koulurakennuksesta ja tarjottava monipuolisia oppimisympäristöjä, jotka motivoivat oppimaan ja rikastavat oppimiskokemusta. (Opetushallitus 2015, 15; Opetushallitus 2019, 19.) Elokuva itsessään on jo oppimisympäristö. Lisäksi puhutaan arvoista, joista elokuvakasvatusta tukevat esimerkiksi kasvattaminen kriittiseen ajatteluun ja kyky asettua toisen asemaan (Opetushallitus $2015,12)$. Lisäksi ainakin suomen kielen ja kirjallisuuden oppimäärään on tulevassa opetussuunnitelmassa uutena kirjattu suoraan maininta elokuvan käytöstä (Opetushallitus 2019, 71). Elokuvakasvatus lisääntyy entisestään.

Lukion opetussuunnitelman perusteiden 2019 tavoitteiksi listataan muiden muassa lukiolaisten hyvinvointi, osallisuus, yhteistyö ja yhteisöllisyys, elämänläheisyyden ja syvällisyyden lisääminen. Kaikki lukion oppiaineet pohjautuvat vuonna 2021 voimaan tulevissa opetussuunnitelmissa kuuteen osa-alueeseen, joista jokainen on liitettävissä elokuvakasvatukseen: hyvinvointiosaaminen, vuorovaikutusosaaminen, monitieteinen ja luova osaaminen, yhteiskunnallinen osaaminen, eettisyys ja ympäristöosaaminen sekä globaali ja kulttuuriosaaminen. (Opetushallitus 2019, 16-17, 61.) Kaikki osa-alueet mahdollistuvat pedagogisesti valittujen hyvien elokuvien avulla. Niitäkään opettajien ei tarvitse itse seuloa, sillä Koulukinoyhdistys tuottaa sopiviin elokuviin asiantuntijoiden tekemiä vapaasti muokattavia ja hyödynnettäviä, opetussuunnitelmiin sidottuja oppimateriaaleja.

\section{Koulukinotoiminta saa osallistuneilta vahvan tuen}

Tein Google Forms -kyselyn Maunulan yhteiskoulun ja Helsingin matematiikkalukion toisen asteen opiskelijoille ja henkilökunnalle. Osaan kysymyksistä pystyi vastaamaan omin sanoin, osassa sai valita itselleen sopivat vaihtoehdot, osassa piti arvioida onnistuneisuutta asteikolla 0-10. Kysymyksiin sai vastata halutessaan nimellä, eikä kaikkiin kysymyksiin ollut pakko vastata. Lukiolaisista kyselyyn vastasi 115, opettajista 19.

Vuosien aikana olemme käyttäneet opetuksessa Elokuvalisenssin alla olevien tuotantoyhtiöiden elokuvia, kun taas tilausnäytäntöihin on valittu elokuvia, joihin Koulukino on tuottanut oppimateriaalin. Kaikki kyselyyn vastanneet opettajat ovat pitäneet elokuvavalintoja onnistuneina, vaikka selkeästi vaikeinta on löytää elokuvia matematiikan ja biologian opetukseen. Kolme tärkeintä seikkaa elokuvavalinnassa opettajille ovat seuraavat: elokuva sopii omaan oppiaineeseen, mahdollistaa oppiaineiden välisen yhteistyön ja elokuvia katsotaan eri genreistä. 


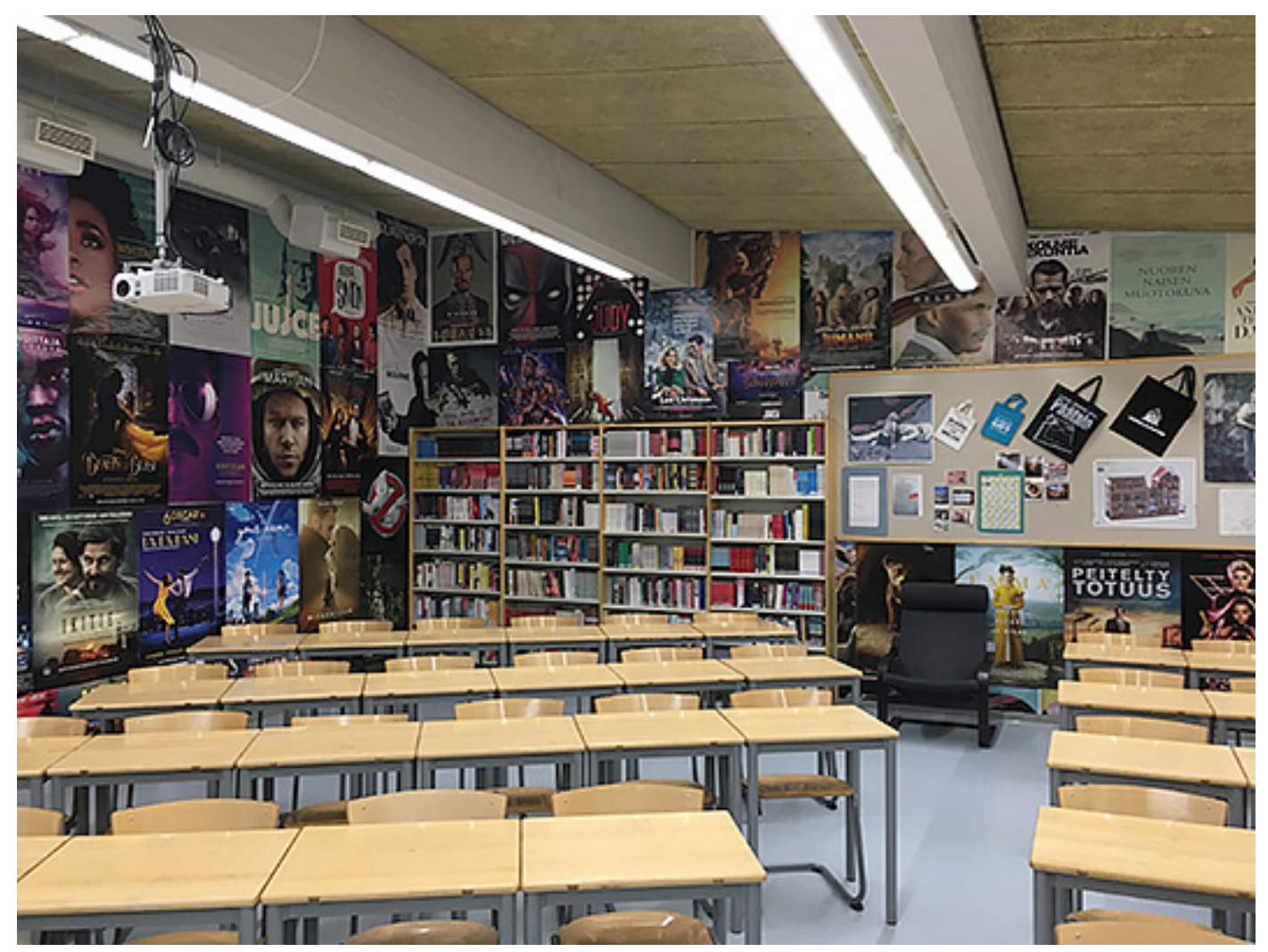

Kuva 3. Opiskelijat ovat saaneet vaikuttaa luokkahuoneen sisustukseen. Julisteseinältä löytyy usein esimerkkejä opetuksessa havainnollistettaviin asioihin. Valokuva: Juha-Matti Tammela.

Lukiolaisista $86 \%$ arvioi elokuvien sopivuuden oppiaineen kursseille ja koulutehtäviin yli seitsemän arvoisina (asteikko 0-10) eli piti koulun valitsemia elokuvavalintoja onnistuneina. Valtaosa valituista elokuvista on ollut sellaisia, joita nuoret eivät ennen elokuvan katsomista pidettyjen "Kuinka moni on nähnyt?"-viittausäänestysten mukaan olleet vapaa-ajallaan nähneet tai olisi menneet katsomaan. Ne harvat, jotka olivat nähneet jo valitun elokuvan, lähtivät mielellään uudestaan. Vaikka kyselyni toteutettiin vain omalla koulullani, Koulukino on mitä ilmeisimmin onnistunut elokuvasuosituksissaan ja oppimateriaaleissaan, jotka materiaalista riippuen tukevat opettajan työtä taustoittamalla ja avaamalla elokuvaa tai jotka voidaan viedä luokkaan sellaisenaan.

Elokuvien käyttö opetuksessa on piristänyt, tuonut vaihtelua ja hyvää mieltä, rentouttanut, laajentanut elokuvamaailmaa, motivoinut kirjoitustehtäviin ja harjoittelemaan sellaisiakin taitoja, joita ei muun muotoisista aineistoista ole aiemmin innostuttu harjaannuttamaan. Monille elokuvat tuntuvat helpommalta aineistolta kuin kirjoitetut tekstit. Lähinnä niille opiskelijoille, jotka käyvät lukio-opintojen ohella töissä tai harrastavat säännöllisesti jotain aktiviteettiä, elokuvareissu on tuottanut stressiä, jos sen päättyminen on mennyt kello 16 jälkeen.

Monille lukiolaisille on ollut yllätys, miten erilaisiin asioihin kurssikaverit ovat kiinnittäneet elokuvissa huomiota. Katsottua elokuvaa on opittu syventämään ja tarkastelemaan eri näkökulmista. Vaikka traileri ei ole kiinnostava, elokuva voi sitä olla. Elokuvien usein laajaksi tunnistettu tematiikka on alettu havaita, ja on opittu esimerkiksi monikulttuurisuudesta, lähihistoriasta ja kuvakulmista. Ylipäätään elokuvaa kokonaisuutena on opittu arvostamaan, vaikka nimenomaan yksityiskohtiin 
kiinnitetään paljon aikaisempaa enemmän huomiota. Erityisen tärkeinä lukiolaiset ovat pitäneet elokuvien käsittelyä, joka on voinut olla keskustelujen lisäksi elokuvaaineistoista kirjoitettujen tekstien yhteissuunnittelua tai -kirjoittamista. Useat oppivat paitsi opettajan myös toisten opiskelijoiden puheenvuoroista.

Se, että elokuviin liittyvän tehtävän on tiennyt etukäteen, on ohjannut tarkastelemaan tavallista keskittyneemmin nähtävää. Elokuvat ovat auttaneet ymmärtämään tapahtumien taustoja, syitä ja seurauksia mieleenpainuvasti ja herättäneet pohtimaan eettisiä kysymyksiä esimerkkitilanteiden avulla. Osa opettajista nosti esille myös sen, että siinä, missä kokonaisteosten luettaminen on monissa ryhmissä haasteellista, elokuvan käsittely onnistuu, sillä kokemus on samanaikainen ja koettu loppuun asti. Se, että voidaan käsitellä katkelmia tai lyhyitä aineistoja laajempaa kokonaisuutta, on tärkeää ja arvokasta, ja elokuvan analysoimisesta opitulla on siirtovaikutus muun muassa kirjallisuuden analyysiin.

\section{Tilausnäytäntö on julkista näytäntöä parempi}

Tilausnäytäntöjä eli koulukinonäytäntöjä voi tilata lähielokuvateatteriin arkisin kello 9-17.30. Useimmiten olemme lähteneet koululta siten, että näytäntöä on päästy alustamaan salissa kello 15.15. Kysyessäni ihanteellisinta aloitusajankohtaa opettajilta iltapäivä vie voiton, vaikka periaatteessa kokoontuminen kello 9 elokuvateatterilla olisi koulun päivittäisen aikataulun puitteissa mahdollista. Opettajat ovat valmiita käyttämään iltapäivän viimeisen oppitunnin elokuvateatteriin siirtymiseen ja mahdollisesti antamaan lukiolaisille yhden vapaatunnin jostain toisesta kohdasta kello 16 jälkeen pitkittyneen päivän vuoksi. Nuorille oleellisinta on, että elokuva on jo päättynyt siihen aikaan, kun koulupäivä muutenkin loppuu. Käytännössä lukiolaiset ovat siis valmiita käyttämään koulukinotoimintaan iltapäivän kaksi viimeistä oppituntia, lähtemään heti ruokailun jälkeen. Koska oppilailla ja opiskelijoilla on oikeus kouluruokaan, useimmissa kouluissa kello 11-13 on tilausnäytännöille mahdoton ajankohta. Elokuvateattereihinkaan tuskin toivotaan etenkään muualta tuotuja eväitä syöviä katsojia.

Kyselyni mukaan erityisesti koulukinonäytännöt ovat hyödyllisiä myös siksi, että opiskelijat kokevat, että elokuvareissut lisäävät ryhmähenkeä, minkä myös opettajat ovat huomanneet. Samalla opitaan tapakulttuuria, ja omalla porukalla oltaessa - ilman julkisten näytäntöjen itselle vieraita katsojia - elokuvan mukana uskalletaan elää. Osallistujia on myös ilahduttanut se, ettei näytäntöjen alussa ole mainoksia, vaan esimerkiksi teatterin tarjoamalla esitystekniikalla toteutettu yhteinen alustus, jossa opastetaan kiinnittämään huomiota tiettyihin seikkoihin elokuvassa ja kerrotaan perustietoa nähtävästä. Elokuvan alustaminen yhteisesti teatterisalissa on koettu hyödylliseksi.

Koulukinokoulu sitoutuu järjestämään lukuvuoden aikana kaksi tilausnäytäntöä. Kaikki kyselyyn vastanneista opettajista ovat valmiit lähtemään elokuviin vähintään kerran, yli 94 \% vähintään kahdesti, yksi jopa kahdeksan kertaa. Lukiolaisista vain 3,6 \% eli neljä opiskelijaa 115:stä ei haluaisi lähteä lukuvuoden aikana ollenkaan elokuviin, 89 \% on valmis lähtemään vähintään kahdesti. Lukiolaisista tilausnäytäntöön lähtisi kymmenen kertaa lukuvuodessa eli noin joka kolmas viikko liki $15 \%$. Into yhteisiin elokuvakäynteihin on siis vielä opettajienkin innostuneisuutta vahvempaa lukiolaisissa.

Käytännön järjestelyihin on oltu tyytyväisiä, ja itsekriittisinä peruskoulun opettajat ja osa lukiolaisistakin näkevät 14-vuotiaiden tarkan valvonnan teatterissa tarpeelliseksi. Vaikka tilausnäytännöissä voi istua minne vain, tietty ryhmä yhdellä koolla helpottaisi valvontaa. Lukiolaisten käyttäytymistä opettajat eivät koe tarpeelliseksi 


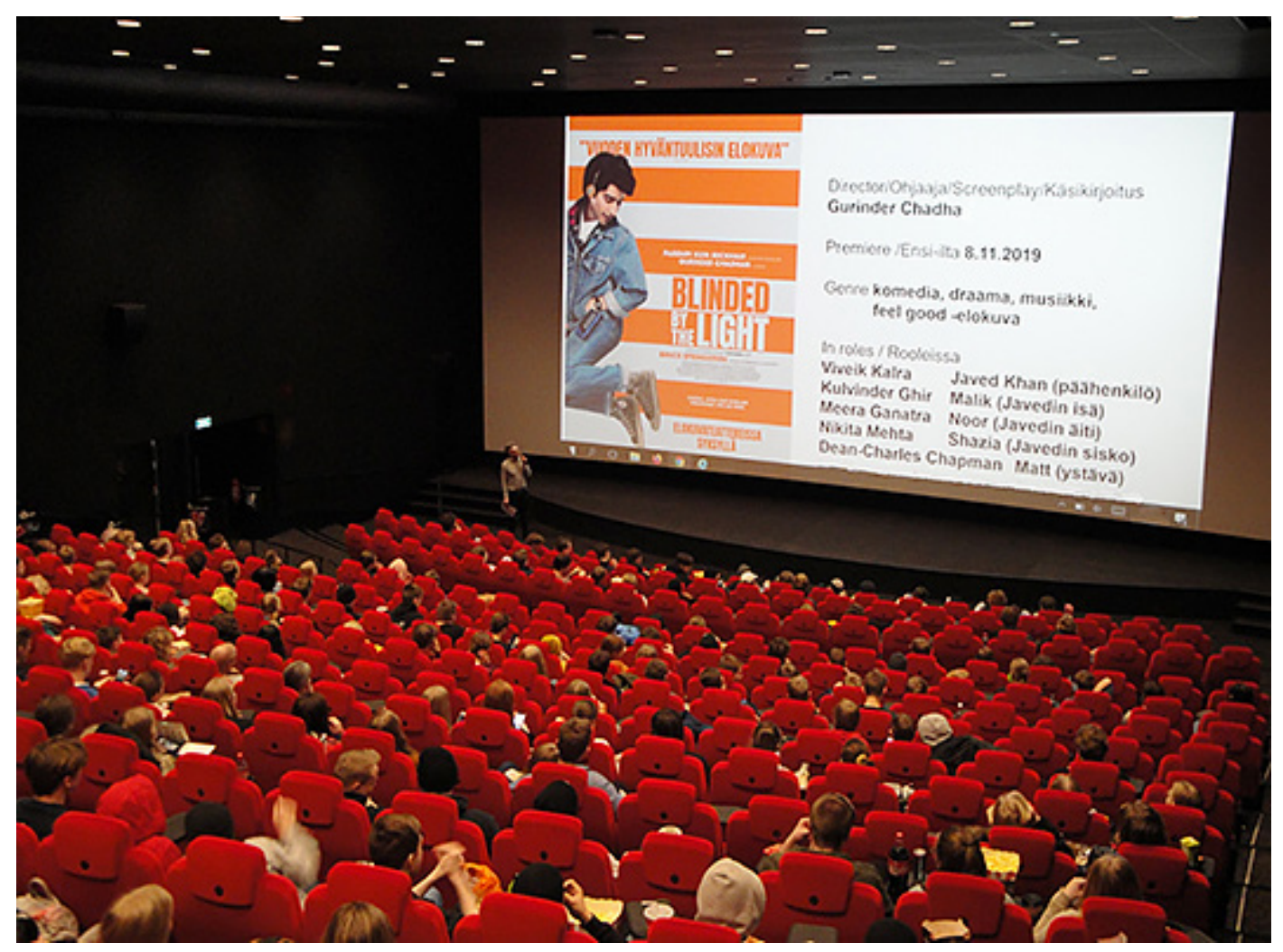

Kuva 4. Elokuvan Blinded by the Light (Iso-Britannia 2019) näytäntöä seurasi 300 Maunulan yhteiskoulun ja Helsingin matematiikkalukion jäsentä: kaikki kahdeksasluokkalaiset, noin 150 lukiolaista ja 15 opettajaa. Koulu maksoi kahdeksasluokkalaisten osallistumisen. Näytöstä edelsi elokuvan alustus ja tietovisa Bruce Springsteenistä. Valokuva: Stella Ruus.

valvoa. Lukiolaiset tahtoisivat omat näytäntönsä ilman peruskoululaisia, ja opettajat kokevat, että lukiolaisten esimerkki rauhoittaa peruskoululaisia. Peruskoululaisten koulukinonäytännöt on hyvä järjestää alkuviikosta, sillä torstaina nähdystä ei muisteta yksityiskohtia maanantaina. Osa lukiolaisista kaipaa lähinnä aiempaa aloitusajankohtaa, ja marginaalinen osa parantaisi tilaisuuksia jakamalla ilmaiset elokuvaliput, virvoitusjuomat ja popcornit.

Peruskoulun puolella elokuviin lähtemisestä tekee vaikean se, että perusopetuksen tulee olla ilmaista, eli koulu ei saa kerätä oppilailta rahaa. Apulaisoikeusasiamies Pasi Pölösen mukaan peruskoululaisia voidaan viedä elokuviin, jos vierailua rahoittaa sponsori tai vanhemmat keräävät varoja vapaaehtoisesti koko ryhmälle. (Pölönen 2018, 6-7.) Siksi peruskouluissa onkin tärkeää mahdollisuus hankkia Elokuvalisenssi ja esimerkiksi Koulukino Suoratoisto - palveluun krediittejä, jotta luokassa voidaan käyttää vaikkapa kotimaisia lyhytelokuvia.

Osa lukiolaisista pitää myös Finnkinon koululaislipun 7,5 euron hintaa kalliina, vaikka se tulee yksittäistä sarjalippua halvemmaksi, ja lähes kaikki pitävät lippua kohtuuhintaisena. Se, että opettajat ja valvojat pääsevät ryhmän mukana ilmaiseksi, on elinehto koulukinonäytäntöjen tilaamiselle. Tarpeen on myös opettajien mahdollisuus käydä katsomassa elokuva etukäteen ilmaiseksi ennen ryhmän tuomista, jotta elokuvan pohjustaminen onnistuu ja jotta elokuvavalinta on ryhmälle ja oppiaineen kannalta onnistunut. Vastaavanlainen käytäntö on useiden näytelmiä esittävien teattereiden kanssa, ja haasteeseen toivotaan myös elokuvateattereiden tai levittäjien reagoivan. 
Kokemus koulukinonäytäntöjen järjestämisestä on osoittanut, että helpointa on kerätä opiskelijoilta lippurahat, joilla koulun taloussihteeri maksaa teatterilta tilatun verkkolaskun. Verkkolasku perustuu juuri ennen näytäntöä ilmoitettuun osallistujamäärään, jolloin viime hetkellä sairastuneet ja asiasta ilmoittaneet voivat vielä saada rahansa takaisin. Verkkolasku on myös nopein tapa, sillä silloin esimerkiksi Finnkinon teattereissa ei tulosteta kaikille erillisiä lippuja, joiden jakamisessa on myös näytännön alussa oma työnsä. Kolikkojen laskeminen teatterilla on hidasta ja vaatii teatterille saapumista yli tuntia ennen näytäntöä, jos on liikkeellä ison joukon kanssa.

\section{"Tarantino Maunulaan"}

Jo ennen Maunulan yhteiskoulun ja Helsingin matematiikkalukion valintaa koulukinokouluksi meillä on vieraillut useita elokuva-alan toimijoita, kuten professori Henry Bacon ja näyttelijät Krista Kosonen ja Antti Luusuaniemi. Kysyessäni toiveita tulevista vierailijoista lukiolaiset mainitsevat Aku Hirviniemen, Quentin Tarantinon, Keanu Reevesin, Michael Bayn ja George Lucasin. Opettajien toiveissa mainitaan Klaus Härö.

Elokuvat kiinnostavat opettajia ja lukiolaisia monipuolisesti, mikä näkyy siinä, että elokuva-alan osaajia toivotaan vierailulle laajasti: tuottajia, ohjaajia, näyttelijöitä, käsikirjoittajia, elokuvamusiikin säveltäjiä ja elokuvaajia. Genreistä mainitaan lähes kaikki, vaikka eniten mainintoja saavat toiminta, jännitys, fantasia ja dokumentit.

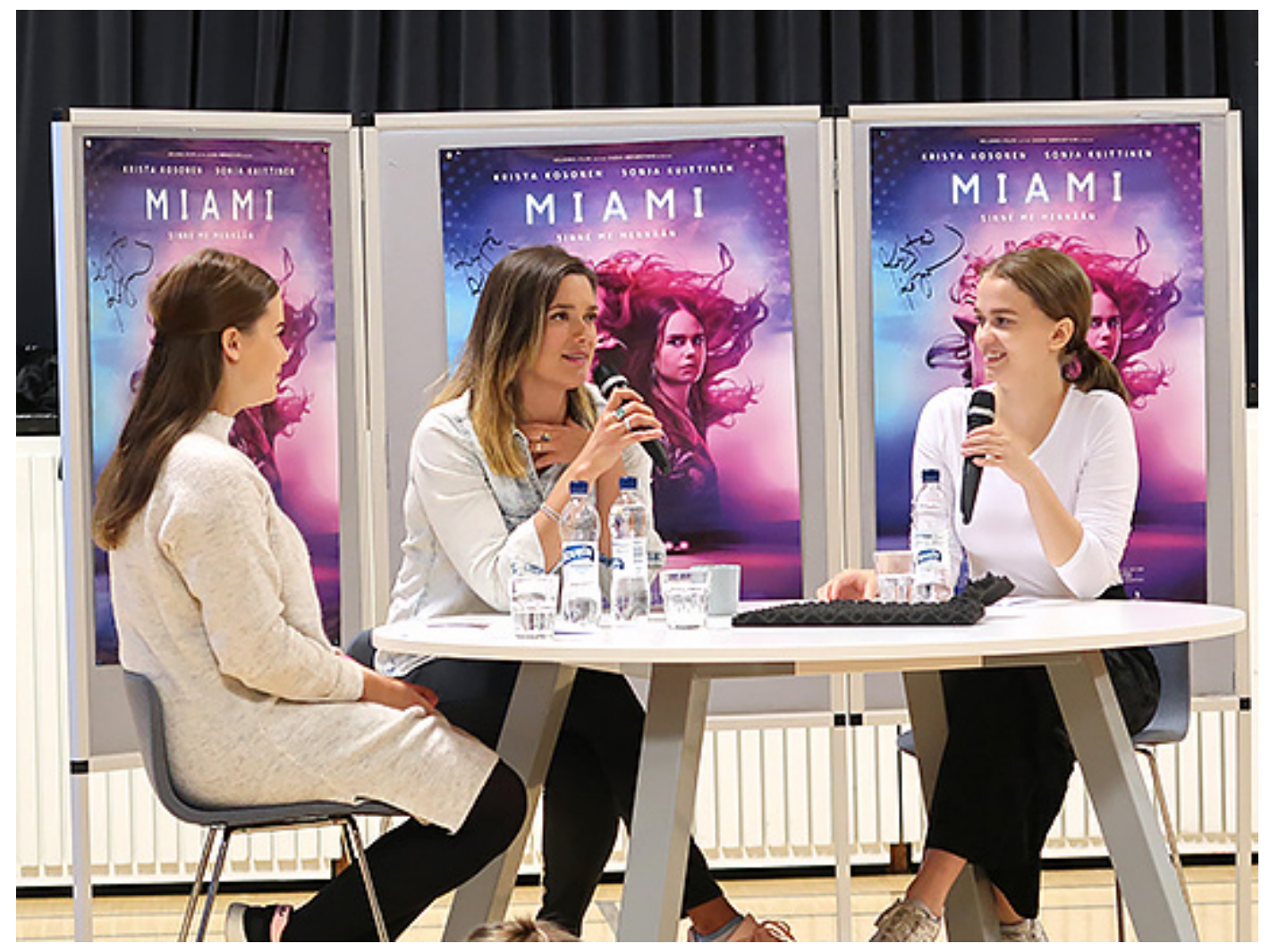

Kuva 5. Näyttelijä Krista Kosonen (keskellä) kertoi koulumme tilausnäytännöissä katsotusta Miami-elokuvasta (Suomi 2017) ja näyttelijän työstä. Paikalla oli yli 300 nuorta. Järjestelyissä opittiin mm. organisointi- ja puheviestinnällisiä taitoja. Elokuva yhdistää äidinkielen, suomi toisena kielenä, psykologian, islamin ja filosofian kurssit. Haastattelijoina vasemmalla Kaisa Saarinen, oikealla Elisa Lilja. Valokuva: Hanna Lempiäinen. 
Opettajilla mainintoja keräävät draama, komedia ja tositapahtumiin perustuvat elokuvat. Klassikoita toivovat tilausnäytännöissä nähtäviksi niin opettajat kuin lukiolaisetkin. Huoli klassikoiden unohtumisesta on myös osalla lukiolaisista, joskin on mahdollista, että opettajat ja opiskelijat viittaavat eri elokuviin puhuttaessa klassikoista.

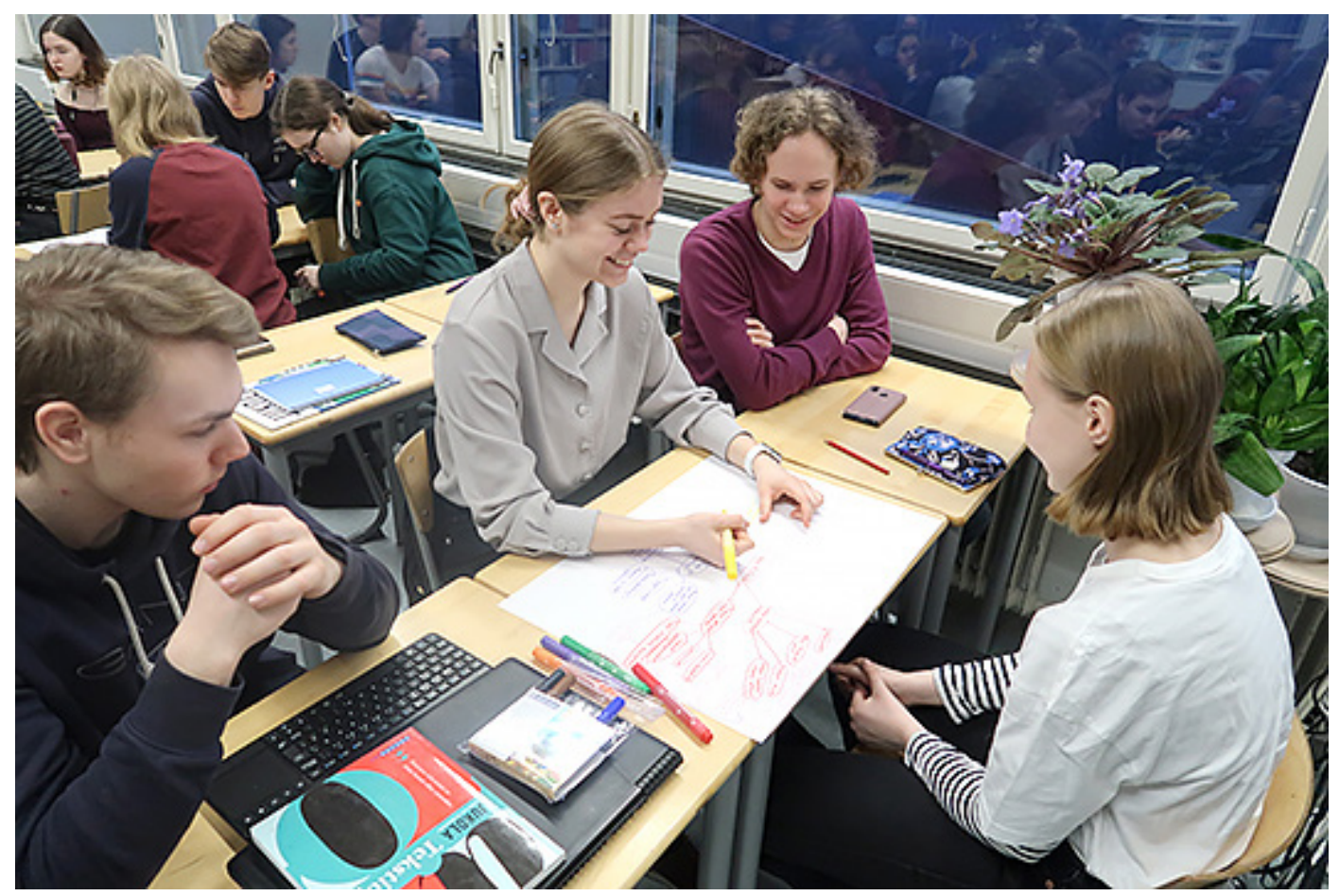

Kuva 6. Sci-fi-elokuva Ad Astra (USA 2019) mahdollistaa fysiikan, filosofian, äidinkielen ja suomi toisena kielenä -kurssien yhteistyön. Jargonin, kielen rekisterin ja moniäänisyyden merkitystä henkilökuvan luomisessa tutkittiin tekemällä pienryhmissä ajatuskarttoja. Kuva: Juha-Matti Tammela.

Elokuva auttaa ja houkuttelee ylittämään myös kouluasterajat peruskoulun ja toisen asteen välillä, minkä aika moni opettajista kyselyssä mainitsi myös tärkeäksi koulukinonäytäntöä suunniteltaessa. Näytännöissä voidaan paitsi toteuttaa opetussuunnitelman mukaista opetusta myös tarjota elämyksellinen oppimisympäristö. Elokuvan käyttäminen osana minkä tahansa oppiaineen opetusta ei ole keneltäkään tai miltään pois, vaan se tuottaa kaikille lisää yhteistä hyvää, mikä auttaa saavuttamaan yhteisen päämäärän: laaja-alaisen yleissivistyksen, kulttuurin, tieteen ja taiteen arvostamisen ja esimerkiksi monilukutaidon. Vaikka elokuvissa istutaan aika hiljaa, se on erinomainen ryhmäytymiskeino matkoineen ja karkinostohetkineen sekä ennen kaikkea elokuvaa seuraavine keskusteluineen. Koulukinokoulut ovat 2020-luvun ilmiö, jolle audiovisuaalisuutta korostavassa maailmassamme on tilausta myös tulevina vuosikymmeninä.

\section{Suositeltavia linkkejä aiheesta}

Koulukinoyhdistyksen verkkosivu (2020). Koulukinonäytännön järjestäminen elokuvateatterissa. <http:// www.koulukino.fi/koulukinonaytannon-jarjestaminen-elokuvateatterissa> (linkki tarkistettu 17.1.2020). 
Koulukinoyhdistyksen verkkosivu (2019). Koulukino Suoratoisto. $<$ https://www.koulukino.fi/suoratoisto/> (linkki tarkistettu 17.1.2020).

Koulukinoyhdistyksen verkkosivu (2020). Ad Astra-oppimateriaali. <http://www.koulukino.fi/ad-astra> (linkki tarkistettu 17.1.2020).

Koulukinoyhdistyksen verkkosivu (2017). Miami-oppimateriaali. <https://www.koulukino.fi/miami> (linkki tarkistettu 17.1.2020).

Koulukinoyhdistyksen verkkosivu (2019). Blinded by the Light -oppimateriaali. <https://www.koulukino. fi/blinded-by-the-light> (linkki tarkistettu 17.1.2020).

Maunulan yhteiskoulun ja Helsingin matematiikkalukion verkkosivu (2019). Koulukinokoulu. <https:// www.mayk.fi/tietoa-meista/koulukinokoulu/> (linkki tarkistettu 17.1.2020).

Viihdepalvelun verkkosivut (2020). Elokuvalisenssi.<https://viihdepalvelu.com/elokuvalisenssi/elokuvalisenssi-vuosilupa/> (linkki tarkistettu 17.1.2020).

Koulukinokoordinaattori Juha-Matti Tammelan blogi (2020). <www.maikkamintissa.fi> (linkki tarkistettu 17.1.2020).

\section{Lähteet}

Koulukinoyhdistyksen verkkosivu (2019). Koulukinokoulu-sertifikaatti. Saatavilla: <www.koulukino.fi/ koulukinokoulu-sertifikaatti> (linkki tarkistettu 17.1.2020).

Opetushallitus (2014). Perusopetuksen opetussuunnitelman perusteet 2014. Saatavilla: <https://www.oph. fi/sites/default/files/documents/perusopetuksen_opetussuunnitelman_perusteet_2014.pdf> (linkki tarkistettu 17.1.2020).

Opetushallitus (2015). Lukion opetussuunnitelman perusteet 2015. Saatavilla: <https://www.oph.fi/sites/ default/files/documents/172124_lukion_opetussuunnitelman_perusteet_2015.pdf> (linkki tarkistettu 17.1.2020).

Opetushallitus (2019). Lukion opetussuunnitelman perusteet 2019. Saatavilla: <https://www.oph.fi/sites/ default/files/documents/lukion_opetussuunnitelman_perusteet_2019.pdf> (linkki tarkistettu 17.1.2020).

Pölönen, Pasi (2018). Maksullinen toiminta perusopetuksessa. Saatavilla: <https://www.oikeusasiamies. fi/r/fi/ratkaisut/-/eoar/1120/2018> (linkki tarkistettu 7.2.2020). 